\title{
In vitro culturing of porcine tracheal mucosa as an ideal model for investigating the influence of drugs on human respiratory mucosa
}

\author{
Eberhard Stennert • Oliver Siefer · Meihua Zheng • \\ Martin Walger $\cdot$ Axel Mickenhagen
}

Received: 6 November 2007 / Accepted: 25 March 2008 / Published online: 6 May 2008

(C) The Author(s) 2008

\begin{abstract}
It has been previously shown that fresh mucosa from different mammals could serve as raw material for in vitro culturing with the differentiation of cilia, which are the most important morphological structures for the function of the mucociliary system. Increasing legal restrictions on the removal of human tissue and changing surgical techniques have led to a lack of fresh human mucosa for culturing. Most of the animals that have been used as donors up to now are genetically not very close to human beings and must all be sacrificed for such studies. We, therefore, established a modified system of culturing mucosa cells from the trachea of pigs, which is available as a regular by-product after slaughtering. With respect to the possibility of developing "beating" cilia, it could be shown that the speed of cell proliferation until adhesion to the coated culture dishes, the formation of conjunctions of cell clusters and the proliferation of cilia were comparable for porcine and human mucosa. Moreover, it could be demonstrated that the porcine cilia beat frequency of $7.57 \pm 1.39 \mathrm{~Hz}$ was comparable to the human mucosa cells beat frequency of $7.3 \pm 1.4 \mathrm{~Hz}$ and that this beat frequency was absolutely constant over
\end{abstract}

Supported by the Jean-Uhrmacher-Institute

E. Stennert $(\varangle) \cdot$ O. Siefer $\cdot$ A. Mickenhagen

Jean Uhrmacher Institute, University of Cologne,

Geibelstrasse 29-31, 50931 Cologne, Germany

e-mail: eberhard.stennert@uni-koeln.de

M. Zheng

Department of Otorhinolaryngology,

Shandong Provincial Hospital, Jing-Wu-Wei-Qi Road 324,

Jinan 250021, Shandong, People's Republic of China

M. Walger

Department of Otorhinolaryngology, University of Cologne,

Kerpener Str. 62, 50937 Cologne, Germany the investigation time of $360 \mathrm{~min}$. In order to prove whether the reaction to different drugs is comparable between the porcine and human cilia, we initially tested benzalkonium chloride, which is known to be toxic for human cells, followed by naphazoline, which we found in previous studies on human mucosa to be non-toxic. The results clearly showed that the functional and morphological reactions of the porcine ciliated cells to these substances were similar to the reaction we found in the in vitro cultured human mucosa.

Keywords In vitro cultured ciliated cells · Porcine · Human · Naphazoline $\cdot$ Benzalkonium chloride

\section{Introduction}

The mucociliary system of the airways plays a decisive role in the defence mechanism for cleaning the air of bacteria, allergens, dust and other foreign particulate matter. It, therefore, has an important protective function for the whole organism. Moreover, it regulates the temperature and humidity of the inhaled air, which are important parameters for the function of the lung.

Because of the importance of these functions, it is vital to possess an effective and reliable evaluation method for observing under constant conditions the reaction of the mucociliary system to the influence of different noxious substances as well as protecting or healing agents.

Until recently, our study group has evaluated these influences using in vitro cultured human nasal mucosa. Increasing legal restrictions on the removal of human tissue and changing surgical techniques have led to a lack of this material. In the past, experiments on the in vitro cultured mucociliary system have been accomplished in several 
mammals, however most of these are not suitable either because of similar legal problems, as in monkeys, or because they are herbivores and therefore, not genetically very close to human beings. Furthermore, to gain fresh mucosa in order to culture mucociliary tissue, it is inevitable that all these experimental animals must be sacrificed.

We, therefore, developed an alternative model by using porcine mucosa from the trachea, which has the advantages, that the pig as an omnivore has a similar biology in comparison to the human being and that the tracheal mucosa is available as a normal by-product after slaughtering.

In order to prove the suitability of the in vitro culturing of this porcine mucosa, we investigated the capability to develop cilia, the minimal time range of their constant beating frequency and the reaction of the cilia to different drugs compared to the reaction of human mucosa.

\section{Materials and methods}

Origin and isolation of porcine tracheal epithelial cells

Respiratory mucosa for cell culturing was harvested from fresh porcine trachea. The porcine-trachea was first cut into halves and cleaned by mechanical brushing in an acetylcysteine solution. The tissue was placed for less than $5 \mathrm{~h}$ into DMEM (Sigma) supplemented with antibiotic/antimycotic solution (penicillin $200 \mathrm{U} / \mathrm{ml}$, streptomycin $200 \mu \mathrm{g} / \mathrm{ml}$ ) and amphotericin B $(0.5 \mu \mathrm{g} / \mathrm{ml})$. To minimize the risk of contamination, the tissue was immersed in $10 \%$ iodine polyvidone (Betaisodona $\left.{ }^{(}\right)$in Phosphate Buffered Saline (PBS) for $3 \mathrm{~min}$ and was then rinsed three times in PBS. After washing, the specimens were immersed in $0.01 \%$ protease from Streptomyces griseus (Sigma) in serum free culture medium for $3-4 \mathrm{~h}$ at $34^{\circ} \mathrm{C}$. By gentle agitation with a scalpel, epithelial cells were released into the medium as single cells, cell clusters and larger mucosal sheaths. After filtration through a stainless steel sieve, the cell suspension was centrifuged at $150 \mathrm{~g}$ for $10 \mathrm{~min}$ and resuspended in a serumfree culture medium $[17,18,20]$.

Origin and isolation of human epithelial cells

Respiratory mucosa for cell culturing was harvested from partial resection of hyperplastic inferior turbinates in rhinosurgery. The patients had preoperatively given their informed consent. For isolating the cells, afterwards we applied the same procedure as for the porcine cells.
Culture medium for porcine and human epithelial cells

Both culture media were a mixture of DMEM and Ham's F12 (Sigma), supplemented with insulin $(1 \mu \mathrm{g} / \mathrm{ml})$, transferrin $(1 \mu \mathrm{g} / \mathrm{ml})$, hydrocortisone $(0.5 \mu \mathrm{g} / \mathrm{ml})$, retinoic acid $(10 \mathrm{ng} / \mathrm{ml})$, L-glutamine $(3.2 \mathrm{mM}), 1.25 \%$ antibiotic/antimycotic solution (penicillin-streptomycin). For the porcine-trachea cells, it was necessary to add a gentamicin and kanamicin solution at a concentration of $0.1 \%$, because this tissue was frequently severely contaminated with bacteria.

Submersion cell culture for porcine and human epithelial cells

Tissue culture dishes (EASY GRIPTM ${ }^{\mathrm{TM}}$ Falcon ${ }^{\circledR}$ ) were used for incubation. The bottom of the culture dishes was coated with extra cellular matrix (ECM) molecules of the basal lamina. The following stock solutions of ECM-molecules were used for coating: $50 \mu \mathrm{l}$ collagen IV [collagen IV $(0.5 \mathrm{mg} / \mathrm{ml})$ in $0.25 \%$ acetic acid], $10 \mu \mathrm{l}$ laminin and $1 \mu \mathrm{l}$ heparan sulphate proteoglycan (HSPG) were added to $1 \mathrm{ml}$ PBS in each culture dish and incubated at $34^{\circ} \mathrm{C}$ for $24 \mathrm{~h}$. The ECM-coating solution was removed and the dishes were washed and filled with the culture medium. The resuspended cells were seeded in submersion in high density on the tissue culture dishes and kept in an incubator (humidified atmosphere, $10 \% \mathrm{CO}_{2}, 34^{\circ} \mathrm{C}$ ). The culture medium was changed every 3 days, [21].

Measurement of ciliary beat frequency

Ciliary beat frequency of cultured cells was measured in a custom-made test facility. An inverted research microscope (DM IRB, Leica) with a heated stage (HT 200, Minitüb) was used. A colour video camera (CCD-Iris/RGB, Sony) relayed the microscope image to a monitor. The culture medium was controlled for temperature (Temperature-Controller HT 1.2, Vetec) and continuously changed (Masterflex digital console drive, Cole-Parmer Instruments) with a rate of $1 \mathrm{ml} / \mathrm{min}$. Thus, different concentrations of the pharmaceutics solution could be completely replaced by the culture medium within $7 \mathrm{~min}$. Temperature and $\mathrm{pH}$-value were constantly controlled in the cell cultures. Each experiment was recorded on videotape. The CBF of single cells was measured according to the following log (Table 1).

$\mathrm{CBF}$ was sampled optically (custom made) from the monitor and computerized by FFT-Analyzer (CF-350 Z, Ono Sokki).

Table 1 Log for measurement of CBF with different pharmaceutics concentrations

\begin{tabular}{lllll}
\hline Concentration & Equilibration & Concentration 1 & Concentration 2 & Rinse out \\
\hline At time $(\min )$ & $0,20,40$ & 60,80 & 100,120 & 140,160 \\
\hline
\end{tabular}




\section{Results}

\section{Constancy}

An adherent monolayer culture of human and porcine ciliated cells (Fig. 1) was present after 4 days in vitro. The ciliary beat frequency of untreated cultured human nasal cells was measured over $180 \mathrm{~min}$ and appeared to be constant at least over this time range $(n=7 ; 29$ single cells, two-sided $t$-test, $P<0.05)$. The ciliary beat frequency of porcine tracheal cells, which was controlled up to $360 \mathrm{~min}$, also remained constant over this time period and additionally showed no significant difference in comparison to the $\mathrm{CBF}$ during the equilibration time $(n=12 ; 53$ single cells, paired $t$-test, $P<0.05)$ (Fig. 2).

\section{Benzalkonium chloride (BAC)}

\section{Human nasal cells}

Increasing concentrations of BAC initially caused an opposing reaction of the $\mathrm{CBF}$ of the cultured human nasal cells (Fig. 3). A concentration of $0.001 \%$ BAC significantly increased the $\mathrm{CBF}$ to $112.73 \%( \pm 17.26, P=0.042)$. But

Fig. 1 SEM-micrograph (scanning electron microscope) from in vitro cultured, untreated $h u$ man nasal mucosa cells (upper row), and porcine tracheal mucosa cells (lower row). Magnification left $\times 400$, middle $\times 3,000$, right $\times 10,000$
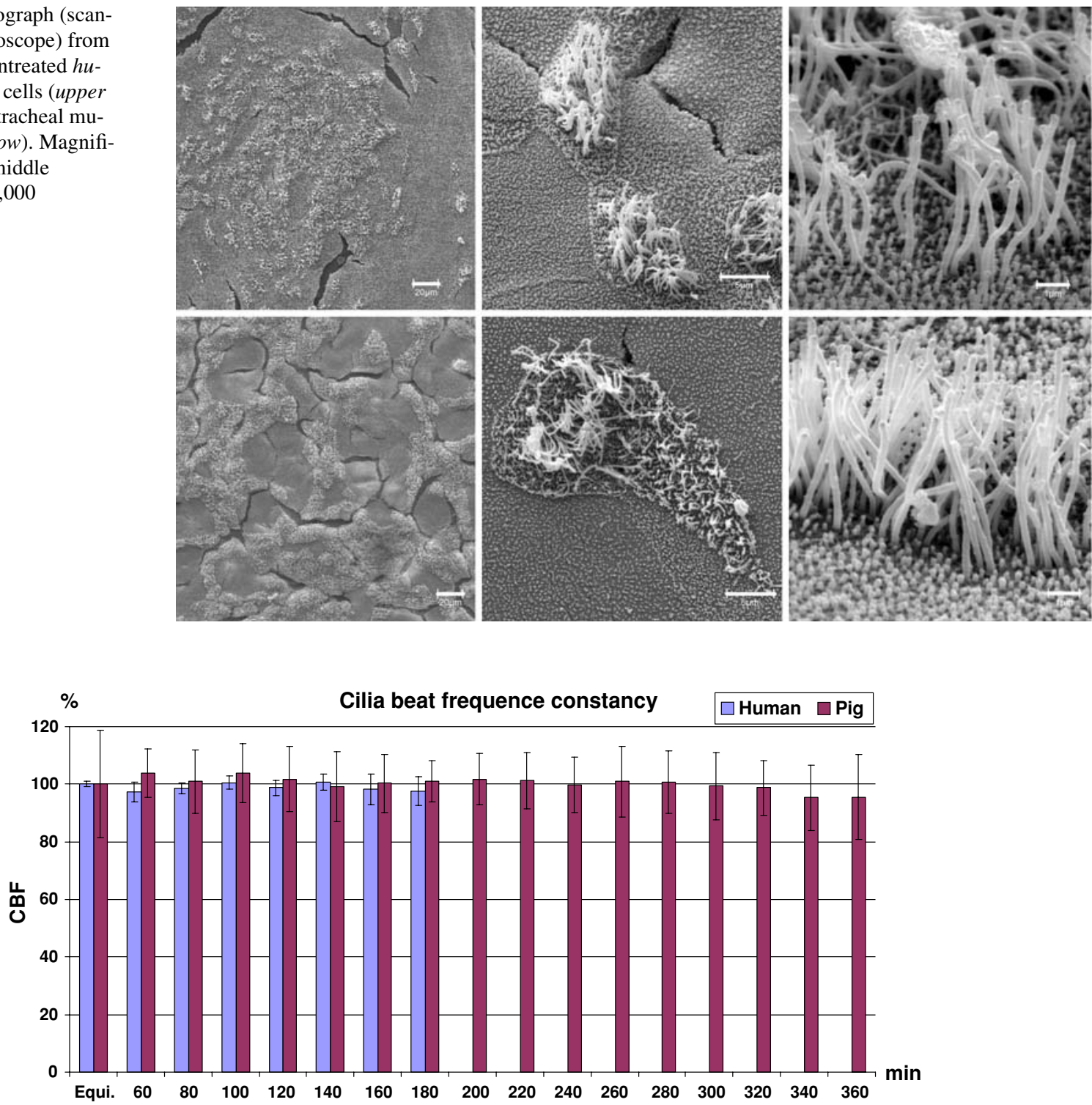

Fig. 2 Ciliary beat frequency of untreated cultured cells from human nasal mucosa (blue columns, $n=7 ; 29$ single cells) and from porcine tracheal mucosa (red columns, $n=12 ; 53$ single cells). No significant difference to the mean frequency gained during the equilibration period
$(100 \%=7.3 \pm 1.4 \mathrm{~Hz}$ for human $/ 100 \%=7.57 \pm 1.39 \mathrm{~Hz}$ for pig $)$ was observed, proving that the $\mathrm{CBF}$ is constant at least during $180 \mathrm{~min}$ for human cells and at least during $360 \mathrm{~min}$ for porcine cells. For reasons of different investigated time ranges see text 


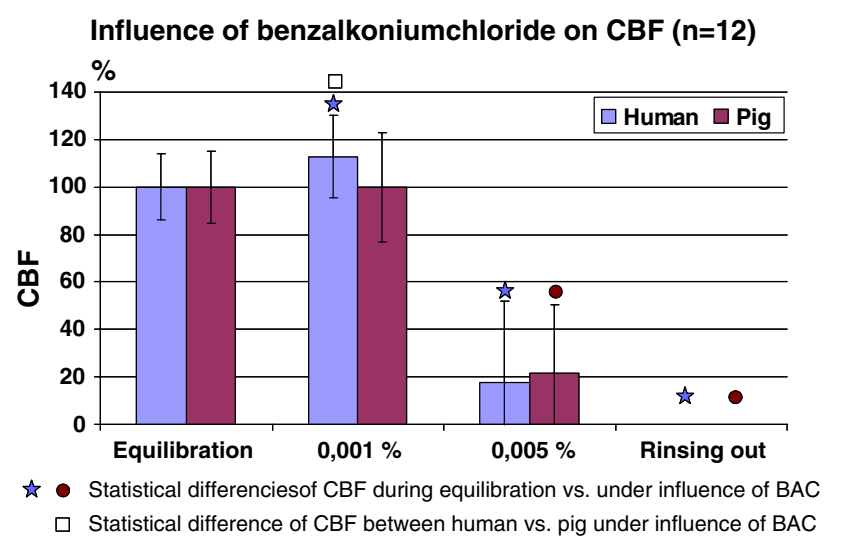

Fig. 3 Influence of benzalkonium chloride (BAC) on the ciliary beat frequency of cultured human nasal mucosa cells (blue columns, $n=12 ; 56$ single cells) and of cultured porcine tracheal mucosa cells (red columns, $n=12 ; 60$ single cells). Only the concentration of $0.001 \%$ shows a slightly significant (open square) difference between human and pig $P=0.0367(\sim P=0.04)$ (paired $t$-test, $P<0.05)$. Concerning the differences between the CBF under the influence of BAC in relation to $\mathrm{CBF}$ during the equilibration period of each species it became evident that in human cells the concentration of $0.001 \%$ primarily caused a significant (filled star) stimulation, whereas the concentration of $0.005 \%$ caused a significant decrease of the CBF relative to the equilibration period (paired $t$-test, $P<0.05$ ). In porcine tracheal cells no change could be seen in the concentration of $0.001 \%$, whereas $0.005 \%$ caused the same significant difference (filled circle) of the CBF relative to the equilibration period (paired $t$-test, $P<0.05$ ). This toxic effect finally led to a total cytolysis in both species, which was not reversible after rinsing out

$0.005 \%$ BAC caused a significant decrease to $17.8 \%$ $( \pm 21.04, P=0.001)$. In addition, $0.005 \%$ BAC caused a complete ciliostatic effect in the entire cell culture, which was not reversible after rinsing out the active substance with substrate-free medium. Finally, not a single cell was beating $(0.00 \pm 0.00 \%, P=0.000)$.

\section{Porcine tracheal cells}

The porcine tracheal cells showed a similar effect of benzalkonium chloride on the ciliary beat frequency (Fig. 3). The concentration of $0.001 \%$ BAC caused no significant variation from the $\mathrm{CBF}$ during equilibration $(99.88 \pm 20.7 \%, P=0.501)$. But the concentration of $0.005 \%$ BAC showed a significant decrease to $21.68 \%$ $( \pm 19.35, P=0.000)$. Finally, the entire cell culture also showed a complete ciliostasis after rinsing out with substrate-free medium. Comparable to the human cell culture, not one cell of cultured porcine mucosa was beating at the end $(0.00 \pm 0.00 \%, P=0.000)$.

\section{Comparison between human versus porcine cells}

In comparison to the human nasal cell culture, the porcine tracheal cells showed only a slightly significant difference at the concentration of $0.001 \%(P=0.0367)$. The other concentration of $0.001 \%(P=0.675)$ as well as the rinsing out $(P=1)$ stimulated equal reactions.

Naphazoline

\section{Human nasal cells}

Increasing concentrations of naphazoline caused no significant stimulation or decrease of the CBF of the cultured human nasal mucosa cells (Fig. 4). Concentrations of $0.01 \%$ $(108.75 \pm 15.84 \%, P=0.237), 0.1 \%(105.99 \pm 16.46 \%, P=$ $0.366)$ and during rinsing out $(104.09 \pm 30.41 \%, P=0.636)$ did not change the $\mathrm{CBF}$ relative to the equilibration.

\section{Porcine tracheal cells}

The porcine-tracheal cells again showed almost the same effect of naphazoline on the ciliary beat frequency (Fig. 4). The concentration of $0.01 \%$ naphazoline caused no significant variation from the equilibration $(103.74 \pm 10.26 \%$, $P=0.319)$. Only the concentration of $0.1 \%$ showed a significant decrease of CBF $(92.46 \pm 21.22 \%, P=0.002)$. However, the rinsing out with substrate-free medium showed that the decrease was statistically also reversible because of lower standard deviation $(80.77 \pm 25.04 \%, P=0.234)$.

\section{Comparison between human versus porcine cells}

Compared to the human nasal cell culture, the porcine tracheal cells showed no significant difference in all concentrations of $0.01 \%(P=0.385)$. The other concentration of $0.1 \%(P=0.051)$ as well as the rinsing out $(P=0.083)$ also caused equal reactions.

\section{Discussion}

There are growing limitations of the removal of human tissue. Following legislation, it is permitted only with written consent of the patients, which increases administrative costs. Further, changing surgical techniques may lead to a lack of human tissue. In order to judge the effect of medicines on ciliary beat frequencies, a sufficient number of primary cultures must always be available.

In the past 30 years (since 1978), experiments on in vitro cultured mucociliary cells have been conducted on the following mammals: monkey [23], cow [30-35], sheep [8, 15, 24-27], rabbit [4, 13, 29, 36, 37], ferret [16, 19], hamster [14] and rat [5, 7, 12, 22, 28].

Cows, ovines, rabbits and hamsters are all herbivore and are therefore not very close to human beings genetically. Closest to the humans are monkeys, but the use of them for 


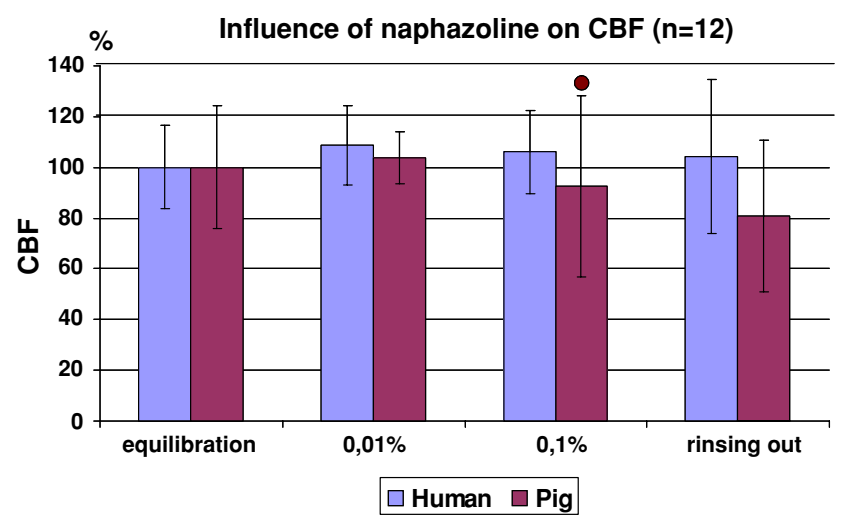

Fig. 4 Influence of naphazoline on the ciliary beat frequency of cultured human nasal mucosa cells (blue columns, $n=12 ; 59$ single cells) and of cultured porcine tracheal mucosa cells (red columns, $n=12 ; 60$ single cells). There is no significant difference between human and pig (paired $t$-test, $P<0.05$ ). The level of significance refers only to the comparison of $\mathrm{CBF}$ under the influence of naphazoline in relation to $\mathrm{CBF}$ during the equilibration period of each species. In human cells, no significance could be seen (paired $t$-test, $P<0.05$ ). In porcine tracheal cells, there was only slight difference between CBF under the influence of $0.1 \%$ naphazoline (filled circle) in relation to $\mathrm{CBF}$ during the equilibration period (paired $t$-test, $P<0.05$ )

experimental studies is also very restricted and not practical for tissue culturing.

Pigs, however, are omnivore and their close biological relationship to humans has been postulated in several studies $[2,3]$. Therefore, they have also been applied especially in experimental xenotransplantion [6]. On the other hand, pigs have been used up to now only three times for in vitro culturing of mucosa [9-11].

To gain fresh mucosa in order to culture mucociliary tissue, it is usually unavoidable that the experimental animals must be sacrificed. The use of porcine-trachea however, has the incomparable advantage that the tissue is a normal by-product of slaughtering of the pigs for food production. Their tracheas are either usually used for dog food or simply discarded.

We, therefore, postulated that pigs might be ideal donors for studying on in vitro cultured mucosa function.

The functional morphology and, especially, the cytoskeleton of the cilia as well as the molecular biology of the ciliated mucosa cells have been intensively investigated by numerous researchers. An overview is given by the famous textbook of Alberts et al. [1]. These authors also point out that the fine structure of the cilia "....is found in almost all forms of eucaryotic flagella and cilia from protozoans to humans." This substantial similarity therefore applies to the whole upper and lower respiratory tract of all mammalians. In order to prove the reliability for testing the comparability of in vitro cultured porcine tracheal mucosa cells with human nasal mucosa cells, we therefore concentrated on the investigation of (a) the capability of developing beating cilia, (b) the constancy of the beat frequency over a sufficient time and (c) the comparability of the reaction of the cilia to different drugs.

The capability of developing beating cilia

In comparison with our previous investigations of in vitro cultured human nasal mucosa cells, we found the following characteristics in the cultured porcine tracheal mucosa:

- The speed of cell proliferation until adhesion to the coated tissue culture dishes happened within approximately $48 \mathrm{~h}$ and was similar to human cells;

- The formation of cell conjugations began as irregular clusters and became increasingly confluent after a few days. This process was also comparable to the human mucosa;

- The proliferation of the cells was associated with a simultaneous growth of cilia as in the human cultures and showed the same appearance (Fig. 1). We did not observe a delayed proliferation of cilia;

- The survival time of its cells with a constant beating frequency is at least as long as the one of human mucosa (Fig. 2).

The constancy of the beat frequency over a sufficient time

From our human experiments, we knew that a maximum investigation period of $180 \mathrm{~min}$ is sufficient for analyzing the effects of naphazoline and benzalkonium chloride. However, to make sure that the cilia of the porcine mucosa hold up the constancy of beat frequency over a time sufficient for testing the influence of various pharmacological substances in this species, we primarily measured the CBF of the porcine tracheal cells up to $360 \mathrm{~min}$. It could be demonstrated, that the CBF was absolutely constant during the whole test period. Therewith we could show that the survival time of the porcine mucosa cells is by far sufficient for those experimental studies.

Moreover, in our previous studies, the human nasal mucosa showed a constant beating frequency of $7.3 \pm 1.4 \mathrm{~Hz}$ over the chosen investigation time of 180 min, whereas the CBF of the porcine mucosa was $7.57 \pm 1.39 \mathrm{~Hz}$, thus demonstrating no statistical difference between both tissues. These findings also confirm that the porcine tracheal mucosa provides optimal prerequisites for investigating the influence of harmful or healing substances on the human mucosa.

The comparability of the reaction of the cilia to different drugs

The main goal of our study was to answer the question whether the reaction of porcine and human cilia to different 
drugs is comparable. Therefore, we initially tested benzalkonium chloride, which we found in previous studies on human mucosa to be highly toxic on the cilia and their beat frequency. The functional and morphological reactions of the porcine ciliated cells to this substance were exactly the same as the reaction observed in the in vitro cultured human mucosa.

From the findings in our experiments with the human mucosa, we demonstrated, on the other hand, that naphazoline as a pure substance has no toxic influence on the survival of the cilia of human mucosa and their beat frequency with different concentrations. The average CBF was $105 \%$ compared with the mean equilibration frequency.

When testing the effect of naphazoline on the porcine mucosa we measured a CBF of $103.7 \%$ using a concentration of $0.01 \%$, which was statistically equal to the CBF of the human mucosa.

With a concentration of $0.1 \%$, the porcine CBF decreased to $92.5 \%$. This value was significantly different to the equilibration period, but it was not significantly different to the human mucosal cells.

After rinsing out the substance, there was a rapid recovery of ciliary function. Whereas the first measurement after 20 min of rinsing out still showed the same CBF as at the end of exposure to naphazoline $0.1 \%$, the $\mathrm{CBF}$ had already recovered to $96.8 \%( \pm 19.6 \%)$ in the second measurement after $40 \mathrm{~min}$.

Although there is no statistical difference, these initial data suggest that the porcine mucosal cells might have a slightly higher sensitivity than the human mucosa cells.

In conclusion, it became evident that the porcine tracheal mucosa can serve as an ideal tissue for the investigation of pharmacological effects on the sensitive physiology of mucosal cilia.

Our future investigations will also include hurtful substances causing neoplastic alteration or allergic reactions, for which this model also seems to be suitable.

In order to achieve comparable results to the earlier investigations with the human mucosa cells, in this study the DMEM culture medium has still been used. Due to our present studies, the airway epithelial cell growth medium (PromoCell) leads to a higher differentiation of cilia and therefore, will be used in our future experiments.

\section{Summary}

The presented data indicate that the in vitro culturing of porcine tracheal mucosa is well suited for investigation of the influence of different noxious substances as well as of protecting or healing agents under constant conditions. In the initial trial with the toxic substance benzalkonium chloride and the non-toxic $\alpha$-symphatomimetic drug naphazoline it could be shown that the reactions of the porcine tracheal mucosa are fairly equal to the reaction of in vitro cultured human mucosa. These results need to be confirmed by further research. Using porcine tracheal mucosa has the significant advantage that living animals do not need to be sacrificed because porcine tracheas are available as a normal by-product after slaughtering. We therefore believe that in vitro cultured mucosa from porcine-trachea can serve as an ideal material for researching the influence of substances affecting or healing human mucosa.

Open Access This article is distributed under the terms of the Creative Commons Attribution Noncommercial License which permits any noncommercial use, distribution, and reproduction in any medium, provided the original author(s) and source are credited.

\section{References}

1. Alberts B, Johnston A, Lewis J, Raff M, Roberts K, Walter P (2002) Molecular biology of the cell. Garland Science, New York

2. Almond GW (1996) Research applications using pigs. Vet Clin North Am Food Anim Pract 12:707-716

3. Bowman TA, Hughes HC (1984) Swine as an in vivo model for electrophysiologic evaluation of cardiac pacing parameters. Pacing Clin Electrophysiol 7:187-194

4. Chevillard M, Lainee P, Robineau P, Puchelle E (1992) Toxic effects of sulfur mustard on respiratory epithelial cells in culture. Cell Biol Toxicol 8:171-181

5. Clark AB, Randell SH, Nettesheim P, Gray TE, Bagnell B, Ostrowski LE (1995) Regulation of ciliated cell differentiation in cultures of rat tracheal epithelial cells. Am J Respir Cell Mol Biol 12:329-338

6. Cooper DK (2003) Clinical xenotransplantion-how close are we? Lancet 362:557-559

7. Davenport EA, Nettesheim P (1996) Regulation of mucociliary differentiation of rat tracheal epithelial cells by type I collagen gel substratum. Am J Respir Cell Mol Biol 14:19-26

8. Frohock JI, Wijkstrom-Frei C, Salathe M (2002) Effects of albuterol enantiomers on ciliary beat frequency in ovine tracheal epithelial cells. J Appl Physiol 92(6):2396-2402

9. Hastie AT, Dicker DT, Hingley ST, Kueppers F, Higgins ML, Weinbaum G (1986) Isolation of cilia from porcine tracheal epithelium and extraction of dynein arms. Cell Motil Cytoskeleton 6:25-34

10. Hastie AT, Patrick H, Fish JE (1990) Inhibition and recovery of mammalian respiratory ciliary function after formaldehyde exposure. Toxicol Appl Pharmacol 102:282-291

11. Joki S, Saano V (1994) Ciliary beat frequency at six levels of the respiratory tract in cow, dog, guinea-pig, pig, rabbit and rat. Clin Exp Pharmacol Physiol 21:427-434

12. Kaartinen L, Nettesheim P, Adler KB, Randell SH (1993) Rat tracheal epithelial cell differentiation in vitro. In Vitro Cell Dev Biol Anim 29A:481-492

13. Lansley AB, Sanderson MJ (1999) Regulation of airway ciliary activity by $\mathrm{Ca} 2+$ : simultaneous measurement of beat frequency and intracellular $\mathrm{Ca}^{2+}$. Biophys $\mathrm{J}$ 77:629-638

14. Lee TC, Wu R, Brody AR, Barrett JC, Nettesheim P (1984) Growth and differentiation of hamster tracheal epithelial cells in culture. Exp Lung Res 6:27-45

15. Lieb T, Forteza R, Salathe M (2000) Hyaluronic acid in cultured ovine tracheal cells and its effect on ciliary beat frequency in vitro. J Aerosol Med 13:231-237 
16. Manawadu BR, Mostow SR, LaForce FM (1978) Local anesthetics and tracheal ring ciliary activity. Anesth Analg 57:448-452

17. Mickenhagen, A (2006) Der Einfluss systemisch und lokal applizierbarer Wirk- und Hilfsstoffe auf die Zilienschlagfrequenz nasaler Flimmerzellen in der Zellkultur. Jean-Uhrmacher-Institut für klinische HNO-Forschung, Universität zu Köln. Ref Type: Thesis/ Dissertation

18. Mickenhagen A, Siefer O, Neugebauer P, Stennert E (2008) The influence of different alpha-sympathomimetic drugs and benzalkoniumchlorid on the ciliary beat frequency of in vitro cultured human nasal mucosa cells. Laryngorhinootologie 87:30-38

19. Mostow SR, Dreisin RB, Manawadu BR, LaForce FM (1979) Adverse effects of lidocaine and methylparaben on tracheal ciliary activity. Laryngoscope 89:1697-1701

20. Neugebauer P, Bonnekoh B, Wevers A, Michel O, Mahrle G, Krieg T, Stennert E (1996) Human keratinocyte culture from the peritonsillar mucosa. Eur Arch Otorhinolaryngol 253:245-251

21. Neugebauer P, Endepols H, Mickenhagen A, Walger M (2003) Ciliogenesis in submersion and suspension cultures of human nasal epithelial cells. Eur Arch Otorhinolaryngol 260:325-330

22. Ostrowski LE, Nettesheim P (1995) Inhibition of ciliated cell differentiation by fluid submersion. Exp Lung Res 21:957-970

23. Robinson CB, Wu R (1993) Mucin synthesis and secretion by cultured tracheal cells: effects of collagen gel substratum thickness. In Vitro Cell Dev Biol Anim 29A:469-477

24. Salathe M, Bookman RJ (1995) Coupling of $\left[\mathrm{Ca}^{2+}\right] \mathrm{i}$ and ciliary beating in cultured tracheal epithelial cells. J Cell Sci $108(\mathrm{Pt}$ 2):431-440

25. Salathe M, Bookman RJ (1999) Mode of $\mathrm{Ca}^{2+}$ action on ciliary beat frequency in single ovine airway epithelial cells. J Physiol 520(Pt 3):851-865

26. Salathe M, Lieb T, Bookman RJ (2000) Lack of nitric oxide involvement in cholinergic modulation of ovine ciliary beat frequency. J Aerosol Med 13(3):219-229

27. Salathe M, Ivonnet PI, Lieb T, Bookman RJ (2001) Agonist-stimulated calcium decreases in ovine ciliated airway epithelial cells: role of mitochondria. J Physiol 531:13-26
28. Salomon DS, Liotta LA, Kidwell WR (1981) Differential response to growth factor by rat mammary epithelium plated on different collagen substrata in serum-free medium. Proc Natl Acad Sci USA 78:382-386

29. Sanderson MJ, Dirksen ER (1986) Mechanosensitivity of cultured ciliated cells from the mammalian respiratory tract: implications for the regulation of mucociliary transport. Proc Natl Acad Sci USA 83:7302-7306

30. Sisson JH, Stoner JA, Ammons BA, Wyatt TA (2003) All-digital image capture and whole-field analysis of ciliary beat frequency. $\mathrm{J}$ Microsc 211:103-111

31. Wyatt TA, Sisson JH (2001) Chronic ethanol downregulates PKA activation and ciliary beating in bovine bronchial epithelial cells. Am J Physiol Lung Cell Mol Physiol 281(3):L575 -581

32. Wyatt TA, Spurzem JR, May K, Sisson JH (1998) Regulation of ciliary beat frequency by both PKA and PKG in bovine airway epithelial cells. Am J Physiol 275:L827-L835

33. Wyatt TA, Schmidt SC, Rennard SI, Tuma DJ, Sisson JH (2000) Acetaldehyde-stimulated PKC activity in airway epithelial cells treated with smoke extract from normal and smokeless cigarettes. Proc Soc Exp Biol Med 225(1):91-97

34. Wyatt TA, Sisson JH, Forget MA, Bennett RG, Hamel FG, Spurzem JR (2002) Relaxin stimulates bronchial epithelial cell PKA activation, migration, and ciliary beating. Exp Biol Med (Maywood ) 227(11):1047-53

35. Wyatt TA, Forget MA, Sisson JH (2003) Ethanol stimulates ciliary beating by dual cyclic nucleotide kinase activation in bovine bronchial epithelial cells. Am J Pathol 163(3):1157-1166

36. Zhang L, Sanderson MJ (2003) Oscillations in ciliary beat frequency and intracellular calcium concentration in rabbit tracheal epithelial cells induced by ATP. J Physiol 546(Pt 3):733-49

37. Zhang L, Sanderson MJ (2003) The role of cGMP in the regulation of rabbit airway ciliary beat frequency. J Physiol 551(Pt 3):765776 